\title{
Renewable Energy for a Sustainable Future
}

\author{
Dear colleagues,
}

It is with great pleasure that we present to you our new international open accessed journal in the field of renewable energy. Renewable energy is a comprehensive and interdisciplinary area, which covers Chemistry, Biology, Chemical Engineering, Mechanic Engineering, Material Science, Economic, Environmental Science, Agricultural Engineering, etc. And this journal would be a prodigious platform for all scientists and engineers working dedicatedly in this field.

Though coal remains as the dominate energy source in China, renewable energy has tremendous growth over the last 15 years. Currently, China was the main demand driver, accounting for more than $80 \%$ of the global market. By the end of 2013, China, the United States, Brazil, Canada, and Germany remained the top countries for total installed renewable power capacity; the top countries for non-hydro capacity were again China, the United States, and Germany, followed by Spain, Italy, and India (REN21 2014). China's new renewable power capacity surpassed new fossil fuel and nuclear capacity for the first time. China lead the world in the production and use of wind power, solar photovoltaic cells, and smart grid technologies, generating almost as much hydro-, wind and solar power as all of France and Germany's power plants combined (Mathews and Tan 2014).

Scientists at the Wuhan Institute of Technology are dedicated to renewable energy researches, including high-value chemicals production from cellulosic biomass, bioseparation technologies, bioprocessing of microalgae, and $\mathrm{CO}_{2}$ capture. We look forward to sharing our progress with all colleagues through this platform.

Congratulations on the launch of Trends in Renewable Energy and best wishes for the success of the journal.

Changyan Yang, Ph.D.

Professor and Vice Dean for Research School of Chemical Engineering \& Pharmacy Wuhan Institute of Technology

\section{REFERENCES}

REN21 (2014). "Renewables 2014 Global Status Report." http://www.ren21.net/portals/0/documents/resources/gsr/2014/gsr2014_full\%20re port_low\%20res.pdf. [Accessed on 2/17/2015]

Mathews, J. A. and Tan, H. (2014). "Economics: Manufacture renewables to build energy security." Nature, 513, 166-168, DOI: 10.1038/513166a.

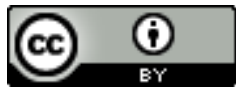

This work is licensed under a Creative Commons Attribution 4.0 International License. 